Apart from reduced output, long hours result in an increase of absenteeism, of which sickness represents approximately half the total loss, although the relationship varies from factory to factory. Some of the casual absence is due to the demands of shopping, to the illness of children or to sheer fatigue. The sickness rate of men almost doubled itself after the 70-hour week was imposed, but the 65-hour week was accompanied by quick recovery. The 60-hour week in the case of women led to a considerable increase of illnesses diagnosed as nervous breakdown. Not only adults but also far too many young persons have been working dangerously long hours, with the result that many are physically and mentally exhausted. Such hours were illegal, but that does not lessen the effect on the health of the young people. The Select Committee on National Expenditure has emphasized the importance of abolishing Sunday labour : in one factory the workers lost more than three times as much time when the hours were raised from 56 a week to $69 \frac{1}{2}$ by means of a longer working day and work on Sunday.

In 1940 the accident-rate of fatal, non-fatal and minor accidents rose considerably above the pre-war level. The employment of inexperienced and young people is partly responsible, but it is also known that the frequency of accidents is influenced by long working hours.

If the worker finds conditions too onerous, he may absent himself altogether. The result is a high labour turnover. To restrict this tendency, in April 1941 the Government introduced the Essential Work Order, according to which no person could leave his employment or be discharged (except for serious misconduct) without the permission of the National Service officer. This had the immediate effect of reducing the labour wastage, but nevertheless in some factories workers have found ways of evading the order.

It is recommended that in the interests of production as well as of health, the ordinary regulations of the Factories Act should be kept except for special temporary conditions. For men a working week in excess of 60 hours usually leads to no increase in production, and for women the hours should never exceed 54. Young women aged sixteen and seventeen should not work more than a 48-hour week, though youths of the same age can do up to 54 hours. Boys and girls aged fourteen and fifteen should be limited to 44 hours.

The importance of limitation of hours of labour has been recognized by the Government for some time, and one result has been an investigation of the effects of war-time hours of labour on young persons. In December 1941 the Government decided that youths and girls aged sixteen and seventeen were to register, so that the local education authorities could make contact with them and that they might be encouraged to fit themselves for national work. Most of the interviewing panels were much impressed by evidence of the strain upon young people due to long hours of work. The actual working hours were rarely excessive, but to the official hours must be added the hours spent in travelling. Also many of the young people were doing two or more jobs; for example, colliery boys doing farm work in the evenings, girls doing normalfactory hours and, in addition, working in fish-and-chip shops or acting as usherettes in cinemas in the evening. In the case of young girls who were running the home while their parents were at work, the interviewers felt that they were often carrying a burden too heavy for their years, leaving very little time for recreation. The interviewers were most impressed by the calibre of the young people and of their general morale, but point out the lack of attention they have received since leaving school. The most alarming symptom was that of mental lassitude in those who were unable to get adequate time for relaxation and recreative activity.

The report of the investigation, which has been issued as a White Paper by the president of the Board of Education and the Secretary of State for Scotland (Cmd. 6446*) outlines the action which it is proposed to take. Hours of employment are to be reviewed, travelling times reduced by transferring youths where necessary to employment nearer their homes, feeding arrangements are to be examined and interviewing panels are to discourage undue activities outside working hours. These steps are all in the right direction, but speed is necessary to prevent undue strain on those who, while they are contributing to the war effort, are also the foundation on which will fall a heavy burden in the early years of peace.

* Board of Education: Scottish Education Department. Youth Registration in 1942. (Cmd. 6446.) Pp. 28. (London : H.M. Stationery Office, 1943.). 6d. net.

\section{FARM AND FOREST IN COLONIAL ADMINISTRATION}

A LMOST alone among the former great Powers, the Anglo-Saxon race has ignored the intimate relation existing between agriculture and forestry. This is as true of the United States of America as it is of the great Dominions of the British Empire and the Colonies under the administration of that Empire. The Anglo-Saxon races all had the same cradle, the island of Britain, and they all seem to lack feeling for the relation of agriculture to the forest. In connexion with future planning of the British country. side, reports have been issued in which the forestry side of this question is either totally ignored or receives scant mention. This want of appreciation in the past of the true role of the forest may have been a natural outcome of the absence for so long of sub. stantial forests in Britain; the large areas of semiderelict land in the mountainous and more out-ofthe-way tracts being practically unknown or, at least, disregarded.

The Anglo-Saxon races have carried with them this lack of appreciation of the value of the forest to agriculture all over the world ; in the New World, the United States and Canada, eastwards to Australia and New Zealand, and many Colonies. But out- 
side Great Britain, the position was very different. Enormous stretches of forest, apparently inexhaustible, were in existence. Since the new-comers had no idea of the value of the forest or its relation to other conditions of the countryside-to mention one, water-a relentless war was waged on these great forests. This war varied. It might be pure lumbering to supply ever-growing markets-wasteful lumbering often accompanied or followed by great fires which swept away large tracts of natural forest as yet unexploited. This type was commonest in the New World. In the more tropical forests in the Old World containing a large number of species of trees, only a few of which had any marketable value, the removal of the salable individuals, while reducing the commercial potentiality, still left a forest on the area. The damage here was due to other but equally destructive practices.

The general results of the maltreatment of the forest in various parts of the world by the AngloSaxon race (or through their instrumentality) during the past century, to go no farther back, are well known, although the results of such treatment are still disputed by administrators and by considerable sections of the public, few of whom in the past were given that modicum of scientific training which would have enabled them to appreciate some of the more elementary laws of Nature. The British Empire was not the only offender. The citizens of the United States have shown equal misunderstanding of Nature and her decrees. Indiscriminate lumbering of the forests and over-utilization of the great corn lands have led to disasters both in the United States and Canada. Excessive sheep farming has occurred in Australia, and uncontrolled firing of the countryside in New Zealand. Soil sterility and erosion have put out of commission thousands of farms.

The reasons and causes of this treatment of the forest and soil may be different, but the aftermath in no way differs from the growing impoverishment, and in cases sterility, of the soils of many British Colonies. The administration of these latter, in that it has put an end to internecine strife between the tribes or chiefs, introduced education, health measures, sanitation and so forth, is as good as can be found anywhere else in the world-in methods often far superior. The British administrations have, however, been guilty of an error of judgment in the rigid application of the early introduced rule that all inter. ference on the part of the administration with the local practices, habits and customs of the people was deprecated and would not be countenanced. Consequently such common practices as shifting cultivation, firing of the countryside in the hot season and unrestricted grazing by herds of stock, increasing with amazing rapidity under the Pax Britannicaall these practices continued unchecked in the form found when the country was taken over. The inevitable results, as in the case of the New World and in the Dominions of the British Empire, were not'foreseen or the dangers even appreciated.

In New Zealand, at least, a recognition of one of the causes of erosion, namely, unchecked firing of the countryside, has begun to make its appearance. In the Dominion Forestry Report (March 1942) on the subject of soil erosion one reads :

"Forest clearing and grassing have ceased on all State-owned lands, and attempts to grow one blade of grass where two trees grew before are now recognized as the root cause of the Dominion's erosion problem. Should further forest clearing be allowed on any lands-private or Native--if it contributes to accelerated erosion? In the belief that the public is convinced of the necessity for controlled clearing of all forested land, irrespective of ownership, appropriate recommendations are being drafted for consideration by the Government."

In how many of the Colonies of the British Empire could such a statement be made ? A great deal has been heard recently of the attempts to improve agricultural methods there. In the past, every effort was made to improve the commercial and financial position-the so-called development of the Colonyby the introduction and growth of crops of tea, coffee, cocoa, sugar, rubber and so forth, all at the expense of the forest, for the development was made by the large-scale felling of the most valuable, because the richest in commercial timber species, of the forest areas. For a time, all went well. Wealth came to the Colony and the planters, while the natives continued their old practices of shifting eultivation, etc., in the rest of the accessible forests. But the rich forest soil, the product of centuries of conservation under the canopy of the trees, gradually became used up and dissipated when exposed, for little protection was afforded to it by the crops grown. We are now facing the results to be expected, and the British taxpayer will be called upon to foot the bill.

The administrations still appear to regard it as a purely agricultural matter. More research, it is said, will lead to a better because more intensive agriculture. Is this a logical conclusion because, in isolated instances, a Colonial agricultural department can show, on a small scale, the example of a success ? In Africa it is beyond question that the soil of the Continent is becoming increasingly impoverished by the very means by which great tracts of that old Continent have become reduced to desert, or practically desert conditions, by man in the past.

It was in justification of this belief that the Royal African Society set up a small Commission of Research for Africa and inyited representatives who had been administrators in those Colonies from the Free French, Belgian and Dutch Governments in London to serve on it. The two British representatives were both retired officials, one a former lieutenant-governor. The Commission came to unanimous conclusions on the subject of shifting cultivation, bush fires, grazing, reservation of forests, and erosion, and suggested practical proposals for dealing with those evils-evils which the administration has refrained from touching for so long, as an interference with the habits and customs of the people. It may be hoped that the Secretary of State for the Colonies may yet find time to study this important problem, vital to the future well-being of the large populations under his care. 